\title{
Effectiveness of Nine Different Fungicides for Management of Crown and Root Rot of Chile Pepper Plants Caused by Phytophthora capsici
}

\author{
Michael E. Matheron and Martin Porchas, The University of Arizona, Yuma Agricultural Center, Yuma, AZ 85364 \\ Accepted for publication 17 November 2015. Published 30 November 2015.
}

\section{ABSTRACT}

Matheron, M. E., and Porchas, M. 2015. Effectiveness of nine different fungicides for management of crown and root rot of chile pepper plants caused by Phytophthora capsici. Plant Health Progress doi:10.1094/PHP-RS-15-0028.

Bell and chile pepper plants are affected by the economically important disease Phytophthora blight, which is caused by the oomycete pathogen Phytophthora capsici. Greenhouse and field trials were conducted to evaluate and compare the ability of nine different fungicides to reduce development of the crown and root rot phase of Phytophthora blight and the resulting chile pepper plant death when applied at 2- and 4-week intervals. Overall, chile pepper plant mortality was significantly decreased in three greenhouse trials with soil applications of fungicide products containing ametoctradin + dimethomorph, cyazofamid, dimethomorph, ethaboxam, fluazinam, fluopicolide, mandipropamid, mefenoxam, and oxathiapiprolin. The same fungicides, excluding mandipropamid and oxathiapiprolin, also significantly reduced overall plant mortality in two field trials. No significant difference was found between 2- and 4-week fungicide application intervals with respect to chile pepper plant survival in any greenhouse or field trial. In general, the degree of reduction in chile pepper plant mortality was lower in field compared to greenhouse trials, probably due to the respective soil surface spray compared to soil drench method of fungicide application used in each instance.

\section{INTRODUCTION}

Bell and chile pepper plants (Capsicum annuum L.) are affected by the economically important disease Phytophthora blight, which is caused by the oomycete pathogen Phytophthora capsici Leonian. This disease occurs in most regions where peppers are grown when climatic conditions favor disease development (Ristaino and Johnston 1999). Symptoms of Phytophthora blight can consist of crown and root rot, wilt, fruit rot, and foliar blight. In Arizona, the first symptoms include wilting along with crown and root rot, followed by plant death. Affected plants typically appear at first in areas of fields where soil remains saturated with water after irrigation (Matheron and Porchas 2000). The number of symptomatic plants can increase rapidly with further irrigations and rainfall occurring from July through September.

Disease management tools that can reduce the incidence and severity of Phytophthora blight on peppers include planting resistant varieties, careful management of irrigation water, growing peppers on raised beds, crop rotation, and use of fungicides (Granke et al. 2012; Sanogo and Ji 2012). When originally registered for use on peppers, the systemic fungicide metalaxyl and subsequently its active isomeric component mefenoxam were widely used to manage Phytophthora blight (Ristaino and Johnston 1999; Simons et al. 1991). Regrettably, resistance to each compound was soon detected within several field populations of $P$. capsici, especially where these fungicides were used exclusively rather than in combination or in rotation

Corresponding author: M. E. Matheron. Email: matheron@ag.arizona.edu.

doi:10.1094/PHP-RS-15-0028

(C) 2015 The American Phytopathological Society with other fungicides (Ristaino and Johnston 1999). Several other fungicides have become available lately in the United States for management of diseases on peppers and other crops affected by $P$. capsici (Jackson et al. 2012; Kousik et al. 2014; Matheron and Porchas 2014). These newer fungicides have several different modes of action that may be used within a fungicide application program as a mixture or in alternation to battle Phytophthora blight as well as to delay the onset of resistance development within populations of $P$. capsici.

The objectives of this research were to: (i) evaluate and compare the ability of nine different fungicides, when applied to soil infested with $P$. capsici, to reduce development of crown and root rot and ultimately chile pepper plant mortality; and (ii) assess the duration of fungicide efficacy by comparing disease severity on plants treated at 2- and 4-week intervals.

\section{PLANT MATERIAL, INOCULATION AND TRIAL PARAMETERS}

Two-month-old chile pepper 'AZ20' transplants, used in all greenhouse and field trials, were produced from seed (Curry Seed $\&$ Chile Co., Pearce, AZ) at a commercial transplant production facility within plastic trays containing 271 cells each $22-\mathrm{mm}-$ square x 60-mm-deep filled with a proprietary peat moss-based planting medium. This chile pepper variety is susceptible to $P$. capsici; however, pepper quality characteristics and yield performance make it a desirable variety in commercial plantings within Arizona and other chile pepper production states. The $P$. capsici isolate EC-2R used as inoculum in these experiments was recovered in 2009 from chile pepper root tissue in a commercial field in southeastern Arizona and was maintained in the laboratory on $\mathrm{V} 8$ juice agar at $25^{\circ} \mathrm{C}$. The isolate was an $\mathrm{A} 2$ mating type, sensitive to mefenoxam, and remained highly virulent throughout the duration of these trials. 
Three greenhouse trials were conducted: Trial 1 with chile pepper plants grown in a commercial potting mix (Scott's Miracle-Gro Co., Marysville, $\mathrm{OH}$ ) and Trials 2 and 3 with plants grown in a silty clay-loam field soil from the University of Arizona Yuma Agricultural Center. The potting mix or soil was infested with $P$. capsici prior to initiation of each trial by incorporation of vermiculite containing the pathogen (Mircetich and Matheron 1976). Briefly, infested vermiculite consisted of 4to 6-week-old cultures of $P$. capsici grown in 2-liter glass flasks at $25^{\circ} \mathrm{C}$ in darkness on a mixture of $1,500 \mathrm{~cm}^{3}$ of vermiculite moistened with $750 \mathrm{ml}$ of $\mathrm{V}-8$ juice broth which was autoclaved at $120^{\circ} \mathrm{C}$ for $30 \mathrm{~min}$ and again $24 \mathrm{~h}$ later before inoculation with the pathogen. The colonized vermiculite medium was rinsed with tap water to remove excess nutrients prior to incorporation into potting mix or soil. In all three greenhouse trials, 2-month-old chile pepper plants were planted individually into 500-mlcapacity plastic pots. Five $\mathrm{cm}^{3}$ of vermiculite infested with $P$. capsici then was placed on the surface of the potting mix or soil in each pot and incorporated to a depth of $2.0 \mathrm{~cm}$. Each fungicide treatment (Table 1) was applied to 10 chile pepper plants as a drench in $200 \mathrm{ml}$ of water per pot, with the amount of each product received per plant indicated in Table 1. Additional drench applications were performed at 2- and 4-week intervals, depending upon the experiment, until trials were terminated approximately 2 months later. Ten additional pots each received $200 \mathrm{ml}$ of water only and served as inoculated control plants. Chile pepper plants were watered daily and fertilized weekly with water-soluble Miracle-Gro fertilizer (15-30-15, Scott's MiracleGro Co., Marysville, OH). To maintain soil moisture, a 10-cmdiameter by $4.0-\mathrm{cm}$-deep container was placed under each pot and filled with water daily. As each trial progressed, the date was recorded when individual plants displayed symptoms of permanent wilting and crown rot. At this point, a chile pepper plant was considered dead as a result of crown and root rot development. The progression of plant death over the course of these trials was measured by recording the number of days that elapsed from experiment initiation until the appearance of these symptoms (Matheron and Porchas 2000). At the end of each trial, final disease severity was determined by recording the number of chile pepper plants that had died. Trials 1,2, and 3 were initiated and terminated, respectively, on 15 October and 15 December 2010; 1 November and 30 December 2010; and 20 April and 29 June 2011. Treatment dates for Trials 1, 2, and 3, respectively, were 15 and 29 October and 12 and 24 November; 1, 15, and 29 November; and 20 April, 4 and 18 May, and 1 and 15 June. Within pots at the 5-cm depth, the range and mean temperatures of potting mix in Trial 1 or soil in Trials 2 and 3, respectively, were 6 to $40^{\circ} \mathrm{C}$ and $22^{\circ} \mathrm{C} ; 6$ to $34^{\circ} \mathrm{C}$ and $21^{\circ} \mathrm{C}$; and 15 to $37^{\circ} \mathrm{C}$ and $23^{\circ} \mathrm{C}$.

A field trial was conducted in 2010 and 2011 at the University of Arizona Yuma Agricultural Center. The soil was a silty clay loam (7-56-37 sand-silt-clay, pH 7.2, O.M. 0.7\%). Two-monthold chile pepper 'AZ20' transplants were planted in single rows, $30 \mathrm{~cm}$ apart on raised beds with $105 \mathrm{~cm}$ between bed centers. Plots of 15 plants per treatment replicate were established within these plantings in a randomized complete block design, with five plants separating each plot within a row and five replicate plots per treatment. At 10 and 7 days after setting transplants in the field in 2010 and 2011, respectively, each 4.5-m-long plot was infested with vermiculite containing $P$. capsici by evenly distributing $150 \mathrm{~cm}^{3}$ of this inoculum in a 5-cm-deep furrow created $7.5 \mathrm{~cm}$ from one side of the row of pepper plants. The inoculum was then covered with soil and the various treatments were applied to each of five replicate plots in $750 \mathrm{ml}$ of water per replicate as a directed spray to the base of plants and bed surface using a $\mathrm{CO}_{2}$-pressurized backpack sprayer equipped with a handheld wand containing a single Tee-Jet flat-fan nozzle. Each plant received the amount of fungicide product listed in Table 1. Additional applications were made at 2- and 4-week intervals for the duration of each trial. Control plots were inoculated with $P$. capsici but not treated with any fungicide. Plants were furrowirrigated weekly for the duration of each trial with enough water to thoroughly saturate the tops of beds to create soil conditions favorable for development of the crown and root rot phase of Phytophthora blight. Final disease severity was recorded by counting the number of dead plants resulting from infection by $P$. capsici when each field trial was terminated. Soil temperature data for the duration of each trial was collected from a nearby Arizona Meteorological Network (AZMET) weather station. For the 2010 trial, chile pepper transplants were set in the field on 7 June, plots were infested with P. capsici on 17 June, and the trial was terminated on 19 August. Fungicide application dates were 18 and 30 June and 14 and 29 July. Soil temperature range and mean values at the $10-\mathrm{cm}$ depth for the duration of the trial were 27 to $37^{\circ} \mathrm{C}$ and $34^{\circ} \mathrm{C}$. In 2011 , chile pepper plants were set in the field on 5 May, plots were infested with $P$. capsici on 12 May, and the trial was terminated on 28 June. Fungicide application dates were 12 and 26 May and 6 and 22 June. Soil temperature range and mean values at the $10-\mathrm{cm}$ depth were 20 to $30^{\circ} \mathrm{C}$ and $24^{\circ} \mathrm{C}$.

No statistically significant difference was found between 2 - and 4-week treatment intervals on the duration of chile pepper plant survival or on the final percentage of plants that died in any greenhouse or field trial; therefore, data for both treatment intervals in each trial were pooled prior to analysis. Data for which the assumptions of homogeneity of variance or normality were not met (individual trial duration of survival and final plant mortality data) were analyzed by the Kruskal-Wallis one-way analysis of variance on ranks nonparametric test, with means compared and separated by the Tukey Test $(P=0.05)$ using SigmaPlot software (Systat Software, San Jose, CA). CoStat statistical software (CoHort Software, Monterey, CA) was used to perform analysis of variance with the GLM procedure for overall duration of survival and final plant mortality data, with means compared and separated at $P=0.05$ according to Fisher's protected least significant difference test. Values for each trial and fungicide application interval were treated as replicates when analyzing treatment data for overall plant mortality and duration of chile pepper plant survival.

\begin{tabular}{|c|c|c|c|c|}
\hline \multicolumn{5}{|c|}{$\begin{array}{l}\text { TABLE } 1 \\
\text { Fungicide materials tested. }\end{array}$} \\
\hline $\begin{array}{l}\text { Active ingredient } \\
\text { (rate in formulated } \\
\text { product, g/liter) }\end{array}$ & $\begin{array}{l}\text { Product } \\
\text { name }\end{array}$ & $\begin{array}{l}\text { FRAC } \\
\text { codey }\end{array}$ & Source & $\begin{array}{c}\text { Formulated } \\
\text { product per } \\
\text { plant }(\mu l)^{z}\end{array}$ \\
\hline $\begin{array}{l}\text { Ametoctradin }(300)+ \\
\text { dimethomorph }(225)\end{array}$ & Zampro & $\begin{array}{l}45+ \\
40\end{array}$ & BASF & 20 \\
\hline Cyazofamid (400) & Ranman & 21 & FMC & 4 \\
\hline Dimethomorph (500) & Forum & 40 & BASF & 9 \\
\hline Ethaboxam (385) & - & 22 & Valent & 15 \\
\hline Fluazinam (500) & Omega & 29 & Syngenta & 40 \\
\hline Fluopicolide (480) & Presidio & 43 & Valent & 6 \\
\hline Mandipropamid (250) & Revus & 40 & Syngenta & 10 \\
\hline Mefenoxam (480) & $\begin{array}{l}\text { Ridomil } \\
\text { Gold }\end{array}$ & 4 & Syngenta & 20 \\
\hline Oxathiapiprolin (100) & Orondis & U15 & Syngenta & 14 \\
\hline
\end{tabular}

y FRAC codes from the Fungicide Resistance Action Committee.

${ }^{\mathrm{z}}$ Amount of formulated product applied per plant. 


\section{CROWN AND ROOT ROT DEVELOPMENT}

Compared to nontreated chile pepper plants, the duration of plant survival was significantly greater for plants treated with mefenoxam in each of the three greenhouse trials and when treated with fluazinam, fluopicolide, mandipropamid, and oxathiapiprolin in two of three trials (Table 2). Considering the overall combined data from all three trials, the duration of chile pepper plant survival was significantly increased with soil applications of ametoctradin + dimethomorph, cyazofamid, dimethomorph, ethaboxam, fluazinam, fluopicolide, mandipropamid, mefenoxam, and oxathiapiprolin. The mean duration of survival for plants growing in soil containing $P$. capsici and treated with these fungicides ranged from 44 to 61 days, compared to 28 days for nontreated plants, in experiments that were on average 64 days long (Table 2).

Final plant mortality was significantly lower when treated with fluazinam, mandipropamid, mefenoxam, and oxathiapiprolin in two of three trials (Table 3 ). Pooled data from all three greenhouse trials revealed that chile pepper plant mortality was significantly reduced by treatment with ametoctradin + dimethomorph, cyazofamid, dimethomorph, ethaboxam, fluazinam, fluopicolide, mandipropamid, mefenoxam, and oxathiapiprolin. Mean reduction in chile pepper plant mortality due to these fungicides ranged from 42 to $87 \%$ compared to nontreated plants (Table 3 ).

The respective mean duration of survival for chile pepper plants treated every 2 and 4 weeks was 48 and 47 days in Trial 1 and 71 and 70 days in Trial 3. Likewise, the respective mean final plant mortality when treated every 2 and 4 weeks was 42 and $45 \%$ for Trial 1 and 8 and $10 \%$ for Trial 3 . In all cases, the difference between the 2- and 4-week application intervals was not significantly different.

In the 2010 and 2011 field trials, final plant mortality compared to nontreated plants was significantly reduced by cyazofamid and fluopicolide in each of the trials and by ametoctradin + dimethomorph, dimethomorph, ethaboxam, fluazinam, and mefenoxam in one trial (Table 4). Considering the collective data for both field trials, chile pepper plant mortality was significantly

\begin{tabular}{|c|c|c|c|c|c|}
\hline \multirow[b]{3}{*}{ Treatment $\mathbf{v}$} & \multirow{2}{*}{\multicolumn{3}{|c|}{$\begin{array}{l}\text { TABLE } 2 \\
\text { ngicides on the dur } \\
\text { fested with Phytoph } \\
\text { lant survival (days)w }\end{array}$}} & \multirow{2}{*}{\multicolumn{2}{|c|}{ Overall }} \\
\hline & & & & & \\
\hline & Trial 1 & Trial 2 & Trial 3 & $\begin{array}{c}\text { Plant survival } \\
\text { (days) }^{\mathbf{x}}\end{array}$ & $\begin{array}{l}\text { Increase in plant } \\
\text { survival (days)y }\end{array}$ \\
\hline Mefenoxam & $53 \mathrm{ab}^{\mathrm{z}}$ & $59 \mathrm{a}$ & $72 \mathrm{a}$ & $61 \mathrm{a}$ & 33 \\
\hline Oxathiapiprolin & $59 \mathrm{a}$ & $51 \mathrm{ab}$ & $72 \mathrm{a}$ & $61 \mathrm{a}$ & 33 \\
\hline Mandipropamid & $42 \mathrm{a}-\mathrm{c}$ & 59 a & $72 \mathrm{a}$ & $58 \mathrm{a}$ & 30 \\
\hline Dimethomorph & 46 a-c & 59 a & $64 \mathrm{ab}$ & $56 \mathrm{a}$ & 28 \\
\hline Fluazinam & $56 a$ & $40 a b$ & $72 \mathrm{a}$ & $56 a$ & 28 \\
\hline Fluopicolide & 58 a & $41 \mathrm{ab}$ & $70 \mathrm{a}$ & $56 \mathrm{a}$ & 28 \\
\hline Ethaboxam & $46 \mathrm{a}-\mathrm{c}$ & $46 \mathrm{ab}$ & $71 \mathrm{a}$ & $54 \mathrm{ab}$ & 26 \\
\hline Ametoctradin + dimethomorph & $34 \mathrm{bc}$ & $47 \mathrm{ab}$ & $71 \mathrm{a}$ & $51 \mathrm{ab}$ & 23 \\
\hline Cyazofamid & $27 \mathrm{c}$ & $34 \mathrm{ab}$ & $72 \mathrm{a}$ & $44 \mathrm{~b}$ & 16 \\
\hline Nontreated control & $28 \mathrm{c}$ & $28 \mathrm{~b}$ & $28 \mathrm{~b}$ & $28 \mathrm{c}$ & 0 \\
\hline
\end{tabular}

${ }^{\mathrm{v}}$ Application rate of each fungicide is provided in Table 1.

${ }^{w}$ The duration of Trial 1, 2, and 3 was 61,59 , and 72 days, respectively.

${ }^{x}$ Overall duration of plant survival is the mean value of the three trials.

y Overall increase in plant survival is the mean value compared to nontreated chile pepper plants.

${ }^{\mathrm{z}}$ Values within a column followed by a different letter are significantly different $(P=0.05)$.

\begin{tabular}{|c|c|c|c|c|c|}
\hline \multirow[b]{3}{*}{ Treatmentv } & \multicolumn{5}{|c|}{$\begin{array}{l}\text { TABLE } 3 \\
\text { of fungicides to reduce chile pepper plant mortality } \\
\text { infested with Phytophthora capsici. }\end{array}$} \\
\hline & \multicolumn{3}{|c|}{ Percentage of plants dead at end of trialw } & \multicolumn{2}{|c|}{ Overall } \\
\hline & Trial 1 & Trial 2 & Trial 3 & $\begin{array}{l}\text { Plant mortality } \\
(\%)^{\mathrm{x}}\end{array}$ & $\begin{array}{c}\text { Reduction in plant } \\
\text { mortality }(\%)^{y}\end{array}$ \\
\hline Oxathiapiprolin & $15 c^{z}$ & $20 \mathrm{ab}$ & $0 \mathrm{~b}$ & $12 \mathrm{c}$ & 87 \\
\hline Fluazinam & $25 \mathrm{bc}$ & $60 \mathrm{ab}$ & $0 \mathrm{~b}$ & $28 \mathrm{bc}$ & 70 \\
\hline Dimethomorph & $50 \mathrm{ab}$ & $0 \mathrm{~b}$ & $40 \mathrm{ab}$ & $30 \mathrm{bc}$ & 67 \\
\hline Fluopicolide & $15 \mathrm{c}$ & $60 \mathrm{ab}$ & $20 \mathrm{ab}$ & $32 \mathrm{bc}$ & 65 \\
\hline Ametoctradin + dimethomorph & $75 \mathrm{ab}$ & $40 \mathrm{ab}$ & $5 \mathrm{~b}$ & $40 \mathrm{bc}$ & 56 \\
\hline Cyazofamid & $85 \mathrm{a}$ & $70 \mathrm{ab}$ & $0 \mathrm{~b}$ & $52 \mathrm{~b}$ & 43 \\
\hline
\end{tabular}

${ }^{\mathrm{v}}$ Application rate of each fungicide is provided in Table 1.

w The duration of Trial 1, 2, and 3 was 61,59 , and 72 days, respectively.

${ }^{x}$ Overall plant mortality is the mean value of the three trials.

y Overall reduction in plant mortality is the mean value compared to nontreated chile pepper plants.

${ }^{\mathrm{z}}$ Values within a column followed by a different letter are significantly different $(P=0.05)$. 
reduced when treated with ametoctradin + dimethomorph, cyazofamid, dimethomorph, ethaboxam, fluazinam, fluopicolide, and mefenoxam. Mean reduction of chile pepper plant mortality due to treatment with these fungicides ranged from 18 to $43 \%$ compared to nontreated plants (Table 4). The respective mean final plant mortality when treated every 2 and 4 weeks was 34 and $29 \%$ in the 2010 trial and 70 and $68 \%$ in the 2011 trial. As noted for greenhouse trials, the difference between the 2- and 4-week application interval in both field trials was not significantly different.

\section{CONCLUSIONS AND DISEASE MANAGEMENT IMPLICATIONS}

Disease development on pepper plants begins when primary inoculum of $P$. capsici in soil initiates root infections that advance to crown infections (Ristaino et al. 1994). Usually, wilting appears before crown rot development in naturally infested soil (Ristaino et al. 1994) and signals impending plant death. The combined data from the three greenhouse trials revealed that ametoctradin + dimethomorph, cyazofamid, dimethomorph, ethaboxam, fluazinam, fluopicolide, mandipropamid, mefenoxam, and oxathiapiprolin significantly reduced disease development and the final number of plants dying due to crown and root rot, compared to nontreated plants. Excluding mandipropamid and oxathiapiprolin, pooled data from both field trials confirmed that these same fungicides reduced final chile pepper plant mortality in the field as well. Recent studies with pepper plants have demonstrated that treatment programs incorporating soil applications of ethaboxam, fluopicolide, and mandipropamid significantly reduced Phytophthora blight of pepper in Michigan (Hausbeck et al 2015), New York (McGrath and LaMarsh 2015), and North Carolina (Adams and Quesada-Ocampo 2015) as well. Ametoctradin + dimethomorph, dimethomorph, ethaboxam, fluazinam, fluopicolide, mandipropamid, mefenoxam, and oxathiapiprolin also were effective at inhibiting growth of stem lesions on pepper seedlings inoculated with mycelium or zoospores of $P$. capsici (Matheron and Porchas 2014). In greenhouse and field trials, Meyer and Hausbeck (2013) found that soil applications of cyazofamid, dimethomorph, fluopicolide, and mandipropamid were highly efficacious in reducing disease progress and symptoms of Phytophthora crown and root rot on summer squash plants grown in soil infested with $P$. capsici.
There were some differences in fungicide performance when comparing greenhouse and field trials in our experiments with chile peppers. Firstly, mandipropamid and oxathiapiprolin significantly reduced final plant mortality in greenhouse but not in field trials. Secondly, cyazofamid was a top performer in field trials, but not so in greenhouse trials. Finally, reduction in plant mortality when treated with effective fungicides ranged from 18 to $43 \%$ in field trials compared to 42 to $87 \%$ in greenhouse trials, even though the amount of active ingredient applied on a per plant basis was the same. A partial explanation for the observed differences in efficacy in greenhouse compared to field trials could be the method of fungicide application to soil. In greenhouse trials, fungicides were applied in an amount of water sufficient to wet all the soil within the root zone. On the other hand, fungicides in field trials were applied as a directed spray to the base of plants and surrounding soil surface, followed later in the day by a furrow irrigation that was expected to move fungicides into the root zone. Differences in efficacy observed in field compared to greenhouse trials may indicate that the expected movement of fungicides into the root zone in field trials did not occur to a sufficient extent to provide the degree of disease control realized in greenhouse trials. Meyer and Hausbeck (2013) did not observe differences in fungicide efficacy between greenhouse and field trials with summer squash grown in soil infested with $P$. capsici. In their greenhouse and field trials, fungicides were applied as a soil drench in $80 \mathrm{ml}$ of water per plant. For greenhouse studies, this was sufficient volume to saturate the potting mix within each container without leaching from the bottom. It is apparent that application of fungicides in the field in sufficient water to move the products into the root zone, perhaps by drip irrigation or chemigation if permitted, is essential to achieve optimum control of Phytophthora crown and root rot caused by $P$. capsici.

The recommended application interval for most fungicides registered in the United States to manage Phytophthora blight on pepper plants ranges from 7 to 14 days. However, in these studies there was no significant difference in chile pepper plant mortality between a 14- or 28-day application interval. Although disease pressure is influenced by climatic as well as other factors (Ristaino and Johnston 1999), these data suggest that application intervals may be extended beyond label recommendations in some cases, thus reducing fungicide costs for the grower.

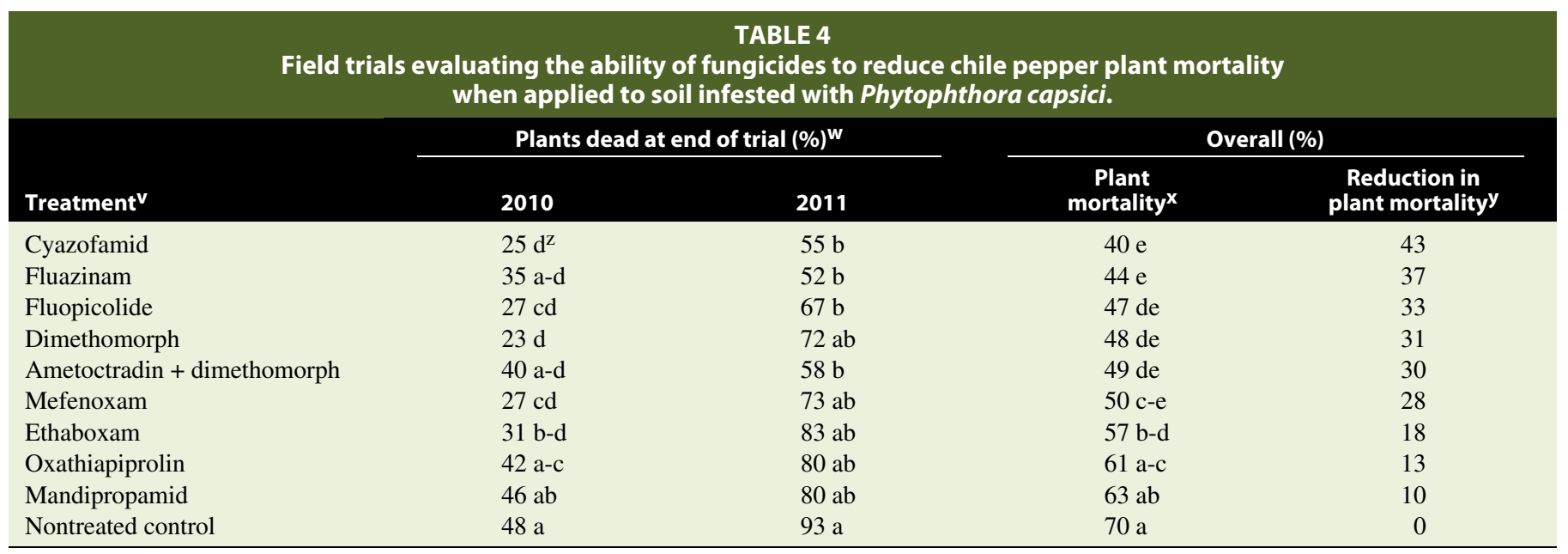

\footnotetext{
${ }^{\mathrm{v}}$ Application rate of each fungicide is provided in Table 1.

${ }^{\mathrm{x}}$ Overall plant mortality is the mean value of the two trials.

y Overall reduction in plant mortality is the mean value compared to nontreated chile pepper plants.

${ }^{\mathrm{z}}$ Values within a column followed by a different letter are significantly different $(P=0.05)$.
}

w Time from placement of $P$. capsici in beds and first application of fungicides to the end of trials in 2010 and 2011 was 63 and 47 days, respectively. 
However, lengthened fungicide application intervals should be avoided when conditions are highly favorable for crown and root rot development.

Production of a green chile pepper crop in southeast Arizona begins with initial seeding in April and ends with harvest about 5 months later, beginning in late August through September. In this region, the threat of Phytophthora blight is associated with summer rainfall that can occur from July through September. It is during this critical 3-month period that growers need to protect their chile pepper crops. Greenhouse and field trials in these studies were terminated after approximately 2 months; however, it is reasonable to expect that comparable results would be obtained if fungicide applications were maintained for a 3-month period to match the time interval that field grown peppers are exposed to Phytophthora blight in commercial chile pepper plantings. Testing of fungicides in commercial fields is needed to validate results obtained from inoculated greenhouse and field trials in noncommercial field plantings. Field trials in commercial pepper plantings can also facilitate quantifying the effect of fungicide treatments on crop yield, which in the final analysis is the most important consideration to growers.

Resistance to some fungicides, such as mefenoxam (Parra and Ristaino 1998) and cyazofamid (Kousik and Keinath 2008), has been documented in populations of $P$. capsici. Delaying occurrence of resistance to fungicides by this pathogen is of paramount importance to fungicide manufacturers as well as endusers. The Fungicide Resistance Action Committee (FRAC) has created management approaches to combat fungicide resistance. One resistance management strategy is to apply a mixture or alternation of products containing active ingredients with different modes of action (Brent and Hollomon 2007). Based on the ability of fungicides to reduce chile pepper plant mortality, the Arizona isolate of $P$. capsici used in these trials was sensitive to ametoctradin + dimethomorph, dimethomorph, ethaboxam, fluazinam, fluopicolide, mandipropamid, and oxathiapiprolin, as well as cyazofamid and mefenoxam, for which resistant populations of the pathogen exist in other geographic areas. Fungicides evaluated in these studies contain several different active ingredients with different modes of action. Following FRAC guidelines, which encourage the use of fungicides with different modes of action within application programs, should help delay resistance development. FRAC assigns a code number to each active ingredient based on its mode of action, so even though products with different trade names may contain the same active ingredient and mode of action, users can readily identify the mode of action by this code number on the label. FRAC publishes an updated list of fungicides and modes of action annually (Fungicide Resistance Action Committee 2015).

This research has provided evidence that the fungicides ametoctradin + dimethomorph, cyazofamid, dimethomorph, ethaboxam, fluazinam, fluopicolide, mandipropamid, mefenoxam, and oxathiapiprolin can significantly reduce crown and root rot development on pepper plants and resulting plant mortality when applied to soil containing $P$. capsici. However, one must not underestimate the potential destruction that this pathogen can inflict in pepper plantings when environmental conditions highly favor disease development. Successful management of Phytophthora blight of pepper plants involves development and implementation of an integrated disease management program. When possible, components of this integrated disease management program should include planting pepper varieties with genetic resistance to the pathogen, using cultural strategies such as management of irrigation water and growing pepper plants on raised beds, rotation to crops not susceptible to $P$. capsici, and the use of fungicides (Granke et al. 2012; Sanogo and Ji 2012).

\section{ACKNOWLEDGMENTS}

The Arizona Department of Agriculture, Agricultural Consultation and Training, has funded this project using Specialty Crop Block Grant funds provided by the USDA, Agricultural Marketing Service. The views or findings presented are the authors' and do not necessarily represent those of the State or the Arizona Department of Agriculture.

\section{LITERATURE CITED}

Adams, M. L., and Quesada-Ocampo, L. M., 2015. Evaluation of fungicides for control of Phytophthora blight of pepper, Jackson Springs, 2014. Plant Dis. Manage. Rep. 9:V084.

Brent, K. J., and Hollomon, D. W. 2007. Fungicide resistance in crop pathogens. How can it be managed. FRAC Monogr. No. 1 (2nd rev. ed.). CropLife International, Brussels.

Fungicide Resistance Action Committee (FRAC). 2015. FRAC Code List 2015: Fungicides sorted by mode of action (including FRAC Code numbering). CropLife International, Brussels, Belgium.

Hausbeck, M. K., Cook, A. J., Naegele, R. P., Krasnow, C. S., and Linderman, S. D. 2015. Evaluation of soil applied fungicide programs for control of Phytophthora blight of pepper, 2014. Plant Dis. Manage. Rep. 9:V091.

Granke, L. L., Quesada-Ocampo, L., Lamour, K., and Hausbeck, M. K. 2012. Advances in research on Phytophthora capsici on vegetable crops in the United States. Plant Dis. 96:1588-1600.

Jackson, K. L., Yin, J., and Ji, P. 2012. Sensitivity of Phytophthora capsici on vegetable crops in Georgia to mandipropamid, dimethomorph, and cyazofamid. Plant Dis. 96:1337-1342.

Kousik, C. S., and Keinath, A. P. 2008. First report of insensitivity to cyazofamid among isolates of Phytophthora capsici from the southeastern United States. Plant Dis. 92:979.

Kousik, C. S., Ikerd, J. L., and Harrison, H. F. 2014. Development of pre- and postharvest Phytophthora fruit rot on watermelon treated with fungicides in the field. Plant Health Progress doi:10.1094/PHP-RS-14-0009.

Matheron, M. E., and Porchas, M. 2000. Comparison of five fungicides on development of root, crown, and fruit rot of chile pepper and recovery of Phytophthora capsici from soil. Plant Dis. 84:1038-1043.

Matheron, M. E., and Porchas, M. 2014. Effectiveness of 14 fungicides for suppressing lesions caused by Phytophthora capsici on inoculated stems of chile pepper seedlings. Plant Health Progress doi:10.1094/PHP-RS-140017.

McGrath, M. T., and LaMarsh, K. A. 2015. Evaluation of biopesticides for managing Phytophthora blight in pepper, 2014. Plant Dis. Manage. Rep. 9:V029.

Meyer, M. D., and Hausbeck, M. K. 2013. Using soil-applied fungicides to manage Phytophthora crown and root rot on summer squash. Plant Dis 97:107-112.

Mircetich, S. M., and Matheron, M. E. 1976. Phytophthora root and crown rot of cherry trees. Phytopathology 66:549-558.

Parra, G., and Ristaino, J. 1998. Insensitivity to Ridomil Gold (mefenoxam) found among field isolates of Phytophthora capsici causing Phytophthora blight on bell pepper in North Carolina and New Jersey. Plant Dis. $82: 711$.

Ristaino, J. B., Larkin, R. P., and Campbell, C. L. 1994. Spatial dynamics of disease symptom expression during Phytophthora epidemics on bell pepper. Phytopathology 84:1015-1024.

Ristaino, J. B., and Johnston, S. A. 1999. Ecologically based approaches to management of Phytophthora blight on bell pepper. Plant Dis. 83:10801089.

Sanogo, S. S., and Ji, P. 2012. Integrated management of Phytophthora capsici on solanaceous and cucurbitaceous crops: Current status, gaps on knowledge and research needs. Can. J. Plant Pathol. 34:479-492.

Simons, J. N., Simons, J. E., and Winsburg, T. 1991. Control of Phytophthora crown rot in bell pepper with directed sprays of metalaxyl. Proc. Annu. Meet. Fla. State Hortic. Soc. 103:120-121. 